\title{
ENDOVASCULAR MANAGEMENT OF INTRACRANIAL ANEURYSMS ON DISTAL ARTERIAL BRANCHES: ILLUSTRATIVE CASE SERIES AND LITERATURE RETROSPECTION
}

\author{
Krešimir Rotim ${ }^{1,2,3}$, Bruno Splavski ${ }^{1,2,3,4}$, Vladimir Kalousek ${ }^{5}$, Mia Jurilij ${ }^{1,2}$ and Tomislav Sajko ${ }^{1,2}$ \\ ${ }^{1}$ Department of Neurosurgery, Sestre milosrdnice University Hospital Centre, Zagreb, Croatia; \\ ${ }^{2}$ University of Applied Health Sciences, Zagreb, Croatia; \\ 3Josip Juraj Strossmayer University of Osijek, Faculty of Medicine, Osijek, Croatia; \\ ${ }^{4}$ Josip Juraj Strossmayer University of Osijek, Faculty of Dental Medicine and Health, Osijek, Croatia; \\ ${ }^{5}$ Department of Radiology, Sestre milosrdnice University Hospital Centre, Zagreb, Croatia
}

\begin{abstract}
SUMMARY - Intracranial aneurysms located on distal arterial branches are sporadic and scarce. They account for $2 \%-7 \%$ of the middle cerebral artery and $0.7 \%-2.3 \%$ of the posterior cerebral artery aneurysms, where they mainly arise distally from the P2-related sites. Such aneurysms usually remain asymptomatic prior to rupture, making their diagnosis and management really demanding. Endovascular treatment comprising of different neurointerventional techniques is becoming the most operational up-to-date routine to approach distal cerebral branch aneurysms. In this single-institution case series, endovascular selective coiling and/or parent vessel occlusion resulted in successful and total aneurysmal exclusion from cerebral circulation, which brought good recovery. Hereby, we present an illustrative case series of distal arterial branch intracranial aneurysms, discussing their possible etiology and various endovascular management modalities. We also provide a literature retrospection concerned with this rare entity. In conclusion, due to their predisposition for rupture, distal branch intracranial aneurysms should be treated early and aggressively. We do believe that endovascular selective coil occlusion is the management method of choice, while parent vessel occlusion (with liquid embolics) is optimal when aneurysmal coiling cannot be achieved, or when distal cortical territory is well vascularized by strong collateral cerebral circulation.
\end{abstract}

Key words: Cerebral arterial branches, distal; Aneurysm, intracranial; Endovascular treatment

\section{Introduction}

Intracranial aneurysms of distal arterial branches are rare ${ }^{1}$. They are usually small and prone to rupture, and they are frequently accompanied by intracranial hemorrhage, which may generate high morbidity/ mortality. Although these aneurysms are predominantly mycotic and mostly caused by bacterial endo-

Correspondence to: Bruno Splavski, $M D, P h D$, Department of Neurosurgery, Sestre milosrdnice University Hospital Centre, Vinogradska c. 29, HR-10000 Zagreb, Croatia

E-mail: splavuno@gmail.com

Received October 7, 2020, accepted November 9, 2020 carditis or other systemic infection ${ }^{2-4}$, additional causes cannot be excluded either. They account for $2 \%-7 \%$ of the middle cerebral artery (MCA) $)^{5-7}$ and $0.7 \%-2.3 \%$ of the posterior cerebral artery (PCA) aneurysms ${ }^{8}$, where they mostly arise distally from the $\mathrm{P} 2$-related sites $^{9}$, but they can also be found more distally.

Cerebral pan-angiography is the most reliable diagnostic tool for determining aneurysms of distal/terminal arterial branches ${ }^{2-4,10}$. However, it is not always easy to identify them prior to rupture, since they usually remain asymptomatic, making their diagnosis and treatment quite challenging ${ }^{11,12}$. Nonetheless, recent developments in endovascular techniques have made 

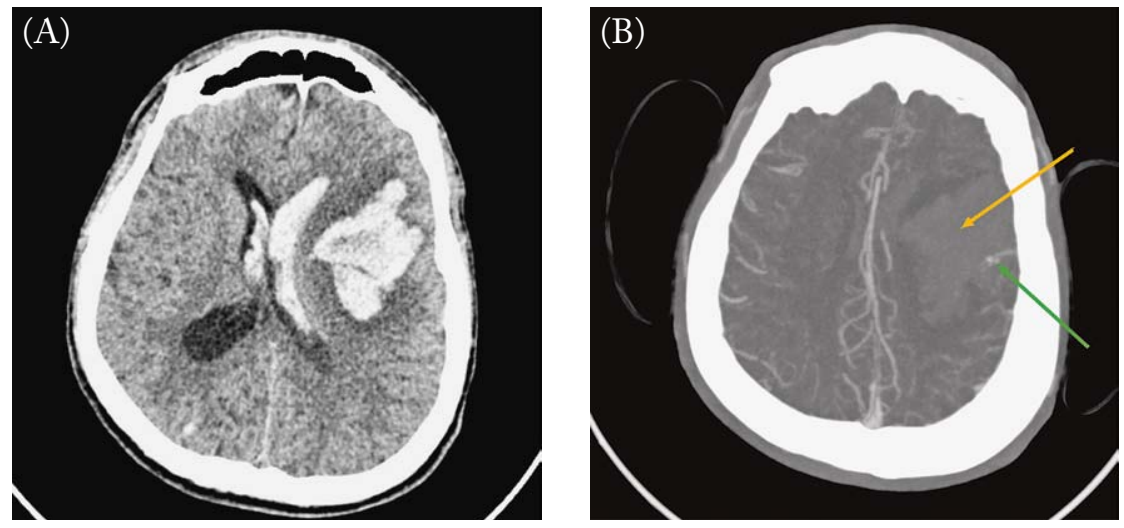

Fig. 1. Axial computed tomography of the brain showing huge left-sided acute intracerebral hematoma accompanied by intraventricular hemorrbage $(A)$; computed tomographic angiography disclosing dysplastic aneurysm on the $M 4$ segment of the left MCA (green arrow), which was located within the intracerebral hematoma (yellow arrow) (B).
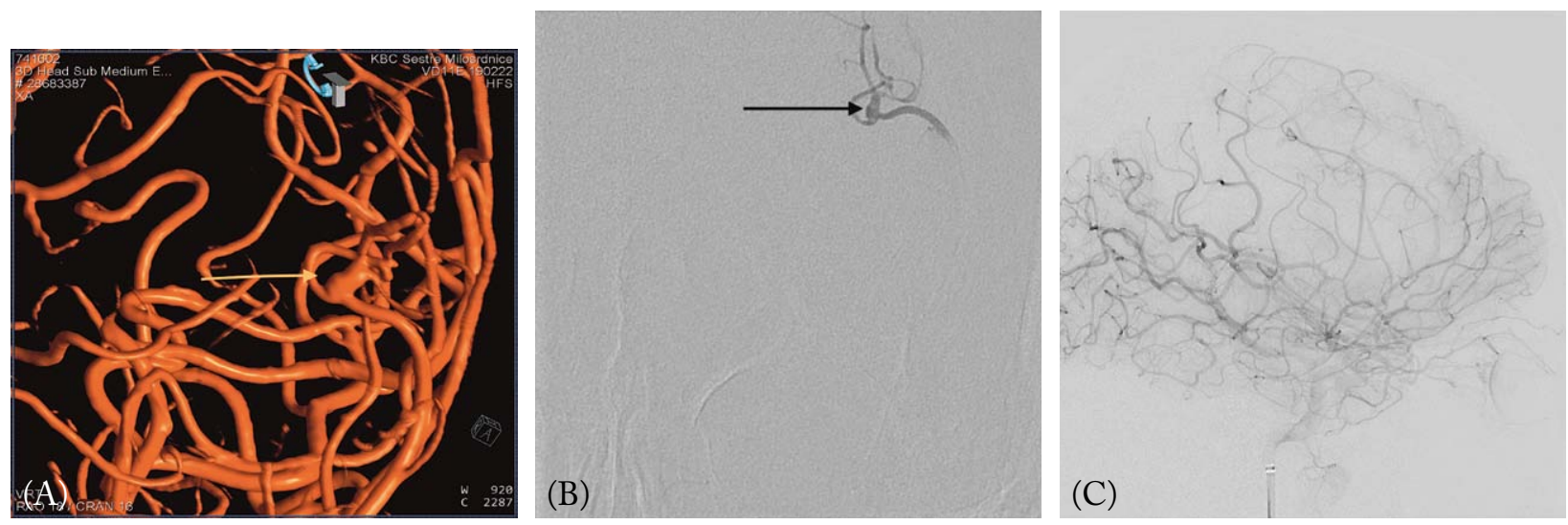

Fig. 2. Brain three-dimensional computed tomographic angiography confirming the M4 segment aneurysm of the left $M C A$ measuring $2.58 \mathrm{~mm}$ in diameter (yellow arrow) (A); cerebral digital subtraction angiography $(D S A)$ illustrating supra-selective endovascular M4 aneurysm occlusion with 8 hypersoft coils (arrow) (B); control cerebral $D S A$ revealing no residual $M 4$ aneurysmal contrast filling $(C)$.

the management of such aneurysms much improved ${ }^{5,13}$. Treatment options consist of regular radiographic follow-ups, and microsurgical clipping, endovascular coiling/stenting/flow diversion, and/or parent vessel occlusion (PVO), regardless of the rupture status. Endovascular treatment comprising of diverse neurointerventional techniques is acquiring more importance lately ${ }^{14}$, becoming the most operational up-to-date routine to approach distal cerebral branch aneurysms ${ }^{15}$.

Hereby, we present illustrative case series of distal branch intracranial aneurysms, discussing their possible etiology and various endovascular treatment mo- dalities, as well as providing a literature retrospection concerned with this rare entity.

\section{Illustrative Case Series}

\section{Case 1. Ruptured aneurysm of the middle cerebral artery} distal branch segment (M4)

A 24-year-old male patient was admitted to the Intensive Care Unit (ICU) as an emergency due to rupture of aneurysm on a distal branch of the left MCA, and subsequent acute subdural and intracere- 


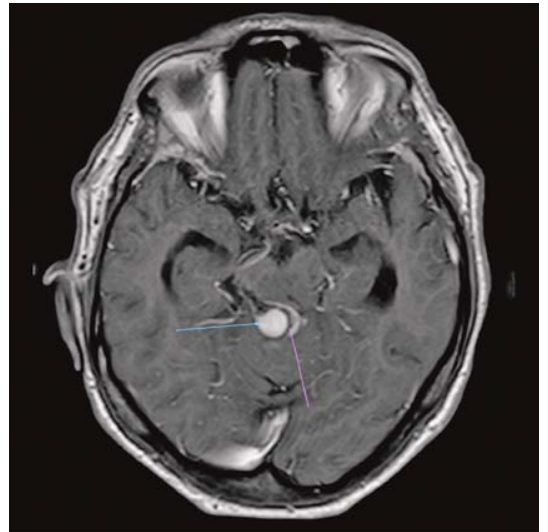

Fig. 3. Contrast enhanced T-1 weighted magnetic resonance imaging of the brain confirming a byperdense lesion localized in the area of quadrigeminal cistern, measuring $1.19 \mathrm{~cm}$ in diameter and mimicking an expansive process. tic aneurysm on the M4 segment of the left MCA, which was located within the ICH (Fig. 1B).

Brain three-dimensional CTA (3D CTA) confirmed the M4 segment aneurysm of the left MCA measuring $2.58 \mathrm{~mm}$ in diameter (Fig. 2A). Cerebral digital subtraction angiography (DSA) confirmed the aneurysm rupture. The supra-selective endovascular aneurysm coiling with eight hypersoft coils was performed during the same procedure (Fig. 2B).

Following endovascular treatment, left-sided decompressive craniectomy and evacuation of $\mathrm{ICH}$ was carried out. Right-sided external ventriculostomy was also performed to relieve intraventricular hemorrhage.

Postoperative brain CT scans showed complete ICH evacuation, while control cerebral DSA revealed no residual aneurysmal contrast filling (Fig. 2C). His immediate postoperative course was complicated with
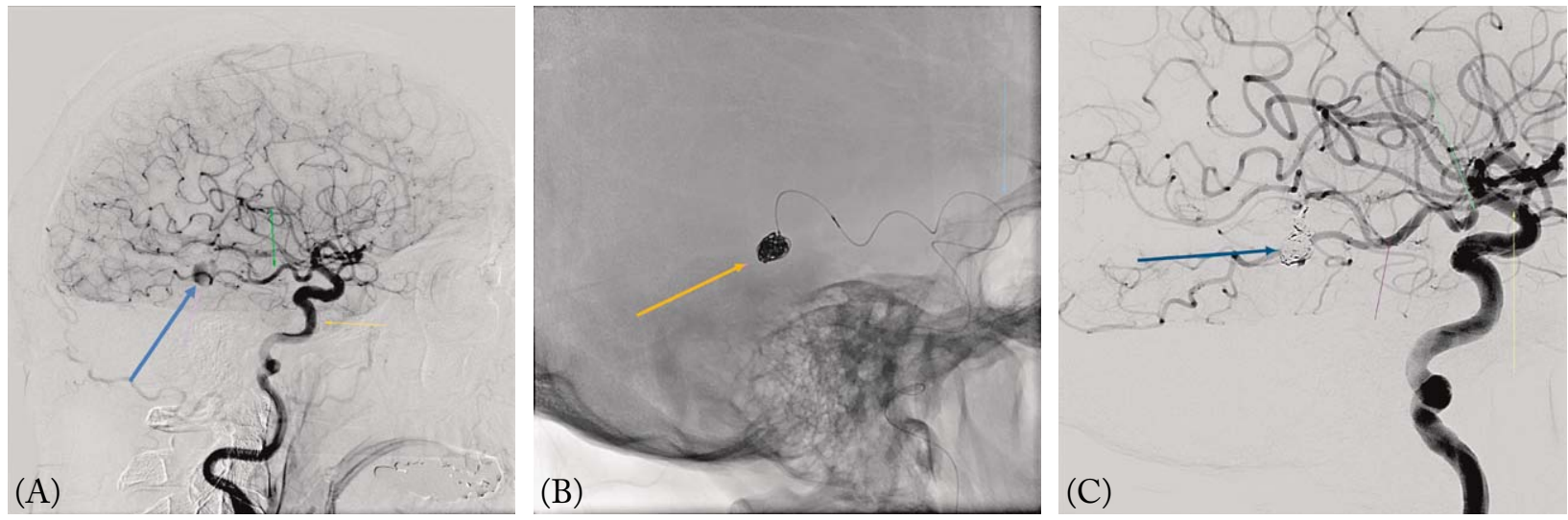

Fig. 4. Digital subtraction cerebral pan-angiography disclosing an expansive process as a large fusiform dissecting unruptured aneurysm measuring $8.9 \mathrm{~mm}$ in diameter and originating from cortical branch of the P4 segment of the right PCA (blue arrow) (A) and illustrating supra-selective endovascular P4 aneurysm 8-coil occlusion (yellow arrow) (B); lateral view of post-procedural cerebral DSA showing complete coil occlusion of the P4 aneurysmal sac with no residual contrast filling (blue arrow) (C).

bral hematoma (ICH) accompanied by intraventricular hemorrhage. The patient was comatose at admission with right-sided hemiplegia. His past medical history included Hashimoto thyroiditis and autism.

$\mathrm{He}$ was treated with broad-spectrum antibiotics (cloxacillin, ceftriaxone) due to right-sided pneumonia. No other symptoms and clinical signs indicative of other active or past systemic infections were found.

Urgent axial computed tomography (CT) of the brain showed huge left-sided acute ICH accompanied by intraventricular hemorrhage (Fig. 1A). Computed tomographic angiography (CTA) disclosed a dysplas- meningitis and ventriculitis, which were successfully managed by broad-spectrum antibiotics (vancomycin, meropenem) for 14 days.

At hospital discharge, his neurological deficit improved to mild contralateral hemiparesis and he was referred for rehabilitation. Follow-up cerebral magnetic resonance angiography (MRA) was recommended at 6 months. 


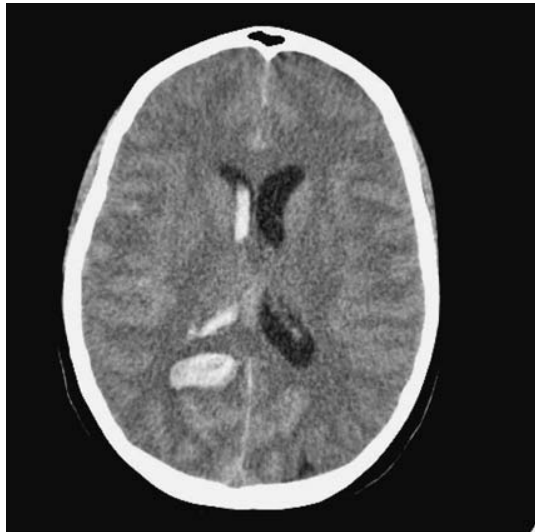

Fig. 5. Axial computed tomography scan of the brain showing diffuse aneurysmal subarachnoid hemorrhage accompanied by intraventricular hemorrhage and right-sided periventricular parieto-occipital intracerebral hematoma.
He showed no clinical signs indicative of active systemic infection.

Contrast enhanced T- 1 weighted magnetic resonance imaging (MRI) of the brain showed a hyperdense lesion measuring $1.19 \mathrm{~cm}$ in diameter, localized in the area of quadrigeminal cistern and protruding towards the fourth ventricle, mimicking an expansive process (Fig. 3). Consequently, the patient acquired lateral ventricular dilatation due to cerebellar and mesencephalic (aqueductal) compression.

Digital subtraction angiography of all four cerebral arterial vessels disclosed the process as a large fusiform dissecting unruptured aneurysm measuring $8.9 \mathrm{~mm}$ in diameter, originating from cortical branch of the $\mathrm{P} 4$ segment of the right PCA (Fig. 4A). It was immediately treated by supra-selective endovascular 8-coil occlusion and selective PVO (Fig. 4B). Post-procedural
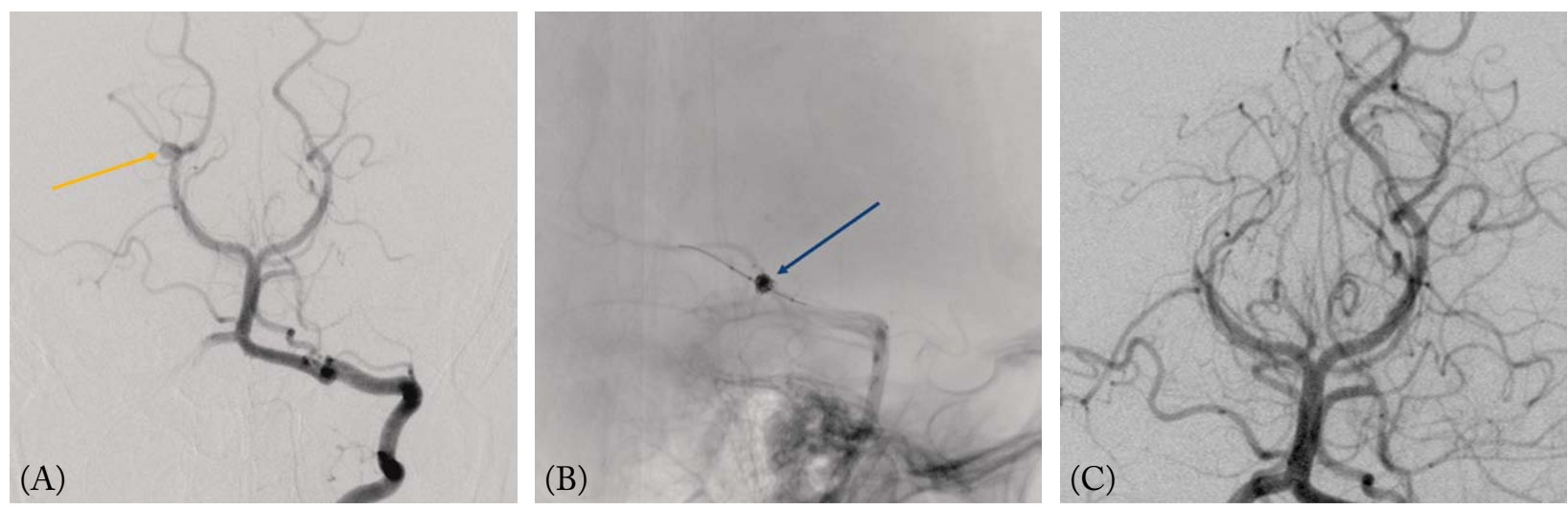

Fig. 6. Repeated digital subtraction angiography (DSA) of cerebral vessels disclosing a dysplastic P2/P3 segment of the right $P C A$ with ruptured pseudoaneurysm measuring $5 \mathrm{~mm}$ in diameter (yellow arrow) (A); lateral view of cerebral DSA illustrating a supra-selective pseudoaneurysm endovascular occlusion with 5 coils (blue arrow) and selective parent vessel occlusion (B); post-procedural angiogram showing no evidence of aneurysmal filling, and patent P3 segment of the right $P C A(C)$.

\section{Case 2. Fusiform dissecting aneurysm of the posterior cerebral artery cortical branch segment $(\mathrm{P} 4)$}

A 74-year-old male patient was admitted to the hospital complaining of acute occipital headache and double vision (horizontal diplopia) accompanied by slight instability while walking (ataxia). His past medical history included arterial hypertension, atrial fibrillation and chronic renal failure. Medical history was negative for traumatic brain or vascular injury, previous neurological disease, and past systemic infection. He was receiving warfarin therapy due to cardiac disorder. cerebral DSA showed complete coil occlusion of the aneurysmal sac with no residual contrast filling (Fig. 4C), while brain CT scanning performed on day 10 post-procedure showed complete resolution of ventricular dilatation.

The patient was discharged after 2-week hospital stay, having no major complaints and without neurological deficit. Repeat cerebral MRA was advised prior to 6-month follow-up examination. 
Case 3. Pseudoaneurysm of the right posterior cerebral artery distal branch segment (P2/P3)

A 34-year-old female patient was admitted to the Neurology ICU due to strong frontal headache, nausea, vomiting, photophobia, and visual-field deficit, followed by a sudden loss of consciousness. Her past medical history included gestational diabetes and urinary bladder cystocele, but it was negative for systemic infection and/or traumatic brain/vascular injury.

Urgent brain CT scan showed diffuse aneurysmal subarachnoid hemorrhage (SAH), accompanied by intraventricular hemorrhage, and right-sided periventricular parieto-occipital ICH (Fig. 5). However, immediate CTA and digital pan-angiography of the cerebral vessels showed no signs of intracranial aneurysm or arteriovenous malformation.

She regained consciousness, but on day 7 of hospital stay, she again complained of a strong onset of headache followed by nausea and vomiting, presumably due to aneurysmal re-rupture. Therefore, repeat brain CT scanning was performed to show progression of intraventricular hemorrhage and right-sided $\mathrm{ICH}$.

Repeat DSA disclosed a dysplastic P2/P3 segment of the right PCA with re-ruptured pseudoaneurysm measuring $5 \mathrm{~mm}$ in diameter (Fig. 6A). Supra-selective pseudoaneurysm endovascular occlusion with five coils and selective PVO were performed during the same procedure (Fig. 6B). Post-procedural angiograms showed no evidence of aneurysmal filling, but the P3 segment of the right PCA was still patent and prone to possible re-bleeding (Fig. 6C). Thus, additional PVO with selective coiling of the dysplastic $\mathrm{P} 3$ segment was performed to exclude it from the circulation.

Following endovascular treatment, the patient was transferred to the ICU, where external ventricular drainage to relieve intraventricular hemorrhage and cerebral edema was carried out a day after. During the immediate postoperative period, she acquired rightsided pneumonia and pleural effusion, which were treated with broad-spectrum antibiotics for 14 days.

Follow-up CTA performed a day after the procedure confirmed no aneurysmal filling, but revealed a zone of acute segmental cerebral ischemia in the irrigation of the right PCA (Fig. 7). Brain CT scan undertaken prior to discharge showed sufficient regression of intracerebral and intraventricular hemorrhage, so ventricular drainage was removed. It also confirmed

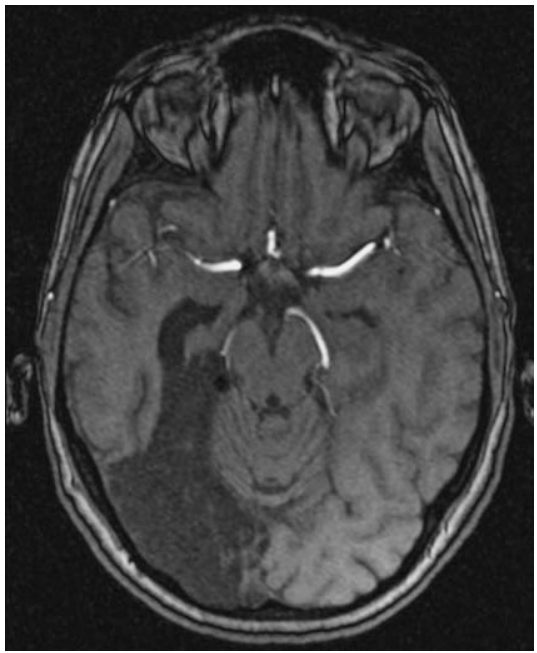

Fig. 7. Computed tomographic angiography performed a day after the procedure confirming no aneurysmal filling, and revealing a zone of segmental cerebral ischemia in the irrigation of the right PCA.

regressive dynamics of ischemic lesion of the right occipital lobe.

The patient was discharged from the hospital and referred to a rehabilitation facility, having homonymous hemianopia and no other neurological deficit. Follow-up cerebral MRA taken at regular check-ups showed no ischemic cerebral lesions and stable aneurysmal occlusion.

\section{Discussion}

In this case series, we encountered one patient with terminal MCA aneurysm (M4) and two patients with distal PCA aneurysms, confirming the reported rarity of distal arterial branch intracranial aneurysms ${ }^{1}$. Although mycotic emboli due to infectious endocarditis remain the most often cause of these aneurysm formation $^{5,15,16}$, vessel wall dissection due to vascular trauma, vasculitis, congenital collagen deficiency, and tumor emboli have also been considered as possible etiologies ${ }^{17-19}$. In our case series, we did not confirm systemic infection as a possible cause of distal aneurysm formation.

Since parent vessel patency is often endangered, outlining the best modality for distal branch aneurysm treatment remains debatable ${ }^{20}$. Considering their rather small size, peripheral location and morphology, microsurgical clipping is quite difficult, being associated 
with high morbidity/mortality ${ }^{21,22}$. Thus, it is better to plan endovascular approach as a preferable treatment method $^{5}$. It may be an excellent choice in a number of patients assuring high occlusion rates and low number of complications when dealing with unruptured aneurysms in particular ${ }^{23}$. Coil embolization may be difficult because of the unfavorable ratio between the size of the aneurysm and the size of the parent vessel ${ }^{9,11}$. Hence, in order to save patency of the parent artery and to reduce the risk of rupture/re-rupture ${ }^{15}$, one has to be particularly careful during coiling of distal branch aneurysms due to their delicate wall. Moreover, those aneurysms that are unsuitable for coil treatment can be injected with intra-aneurysmal glue as a capable substitute to endovascular coiling ${ }^{11}$. Recently, the use of flow-diverting stents for intracranial aneurysms located on distal arterial branches has also increased ${ }^{24}$. Nevertheless, due to the smaller diameter of such vessels, the rate of flow limitation leading to the broader segmental cortical ischemia remains debatable ${ }^{25}$. Hence, if the patency cannot be kept, or when distal cortical territory is well vascularized by strong collateral circulation, selective PVO has to be taken into consideration $^{5,14,23,26}$. One has also to bear in mind the potential risks of PVO such as segmental ischemia in the parent vessel territory, and perforator injury during microcatheter navigation ${ }^{9,27}$. We managed to treat all our cases by supra-selective endovascular coiling or selective PVO with liquid embolics successfully, trying to avoid segmental cerebral ischemia.

The main restriction of endovascular treatment is aneurysmal morphology, where the presence of a wideneck aneurysm is the most important limitation ${ }^{11}$. Therefore, some distally located aneurysms can be treated with PVO in the cases where selective aneurysmal occlusion cannot be achieved ${ }^{9}$. In spite of that, it seems that parent vessel-preserving strategies are as effective as PVO techniques in providing protection from aneurysmal re-bleeding ${ }^{28}$. Thus, it appears that endovascular treatment of such aneurysms can be safe, irrespective of the use of selective coil embolization or $\mathrm{PVO}^{27}$. In our case series, endovascular coiling and/or selective PVO resulted in total and stable aneurysmal occlusion, assuring enough protection from early rebleeding and good recovery. However, it seems that management outcome of such aneurysms is primarily dependent on their location, morphology, complexity and status of rupture.
Dissimilar to other intracranial aneurysms, those on distal PCA branches have a tendency to be larger, dissecting and tortuous ${ }^{29,30}$. Such aneurysms often remain concealed prior to rupture, which is always accompanied by spontaneous $\mathrm{SAH}$ and/or intracerebral/ intraventricular hemorrhage ${ }^{30}$. Symptoms of aneurysmal rupture include sudden onset of severe headache, nausea and vomiting, frequently accompanied by visual field loss/deficit due to proximity to the upper brain stem and lower cranial nerves ${ }^{29,31}$, which was the case in both of our patients too. Since the prognosis of ruptured posterior circulation aneurysms is reported to be poor $^{32}$, they should be aggressively treated early ${ }^{33}$, preferably engaging different endovascular occlusion techniques, including selective aneurysmal occlusion, and $\mathrm{PVO}^{30,31,34,35}$. Accordingly, we treated both of our PCA aneurysm patients by aneurysmal coil occlusion and selective PVO, which resulted in satisfactory outcome. On the contrary, to our knowledge from the literature, patients with distal PCA were mainly treated with deliberate $\mathrm{PVO}^{36}$, either at the level of the aneurysmal neck only ${ }^{37,38}$, or when non-saccular aneurysms were encountered ${ }^{39}$.

Pseudoaneurysm formation after rupture of an intracranial distal aneurysm is an exceptionally rare but high-mortality lesion that occurs in less than $1 \%$ of all brain aneurysms ${ }^{40,41}$. Although such an aneurysm is usually a consequence of brain injury, vessel wall dissection, mycotic infection, or congenital collagen deficiency ${ }^{42,43}$, the etiology, pathophysiology, natural history, as well as modality of treatment have not been fully recognized yet, and remain controversial ${ }^{41}$. Spontaneous pseudoaneurysm without any traumatic or infectious history is very rare, but likely a cause of intracranial hemorrhage ${ }^{44}$. This aneurysm can be diagnosed using CTA and DSA, but it cannot always be detected with both modalities simultaneously due to differences in timing of examinations, and oscillation of intracranial pressure ${ }^{43}$. Nevertheless, pseudoaneurysms can be safely and effectively treated by coil embolization ${ }^{42}$, as well as by total PVO. Such was the case in our last patient who was not initially angiographically diagnosed, and who was successfully treated with endovascular coiling and selective liquid PVO due to spontaneous false aneurysm of the P2/3 segment of the right PCA causing SAH, ICH and intraventricular hemorrhage after repeated rupture. 
In conclusion, due to their predisposition to rupture, distal branch intracranial aneurysms should be treated early and aggressively regardless of their predominantly small dimensions. We do believe that selective endovascular coil occlusion is the most appropriate management method, while liquid or glue PVO are treatment choices when the parent vessel has to be scarified. To achieve a favorable outcome, a tight teamwork between neurointerventionists and neurosurgeons is crucial, while treatment modality should be personalized for each patient.

In the last part of this article, we have to underline that this paper is intended to be an institutional series report only. Therefore, no ultimate recommendations are made on the topic of the best treatment option, urging additional learnings.

\section{References}

1. Chapoulka J, Putman C, Awad I. Endovascular therapeutic approach to peripheral aneurysms of the superior cerebellar artery. AJNR Am J Neuroradiol. 1996;17:1338-42.

2. Ducruet AF, Hickman ZL, Zacharia BE, Narula R, Grobelny BT, Gorski J, et al. Intracranial infectious aneurysms: a comprehensive review. Neurosurg Rev. 2010;33(1):37-46. doi: 10.1007/ s10143-009-0233-1.

3. Messori A, Lanza C, De Nicola M, Menichelli F, Capriotti T, Morabito L, et al. Mycotic aneurysms as lethal complication of brain pseudallescheriasis in a near-drowned child: a CT demonstration. AJNR Am J Neuroradiol. 2002;23(10):1697.

4. Peters PJ, Harrison T, Lennox JL. A dangerous dilemma: management of infectious intracranial aneurysms complicating endocarditis. Lancet Infect Dis. 2006;6(11):742-8. doi: 10.1016/ S1473-3099(06)70631-4.

5. Baltacioğlu F, Cekirge S, Saatci I, Öztürk H, Arat A, Pamir N, et al. Distal middle cerebral artery aneurysms. Endovascular treatment results with literature review. Interv Neuroradiol. 2002;8(4):399-407. doi: 10.1177/159101990200800409.

6. Gibo H, Carver CC, Rhoton AL Jr, Lankey C, Mitchell RJ. Microsurgical anatomy of the middle cerebral artery. J Neurosurg. 1981;54:151-69.

7. Rinne J, Hernesniemi J, Niskanen M, Vapalahti M. Analysis of 561 patients with 690 middle cerebral artery aneurysms: anatomic and clinical features as correlated to management outcome. Neurosurgery. 1996;38:2-11. doi: 10.1097/00006123199601000-00002.

8. Ferrante L, Acqui M, Trillò G, Lunardi P, Fortuna A. Aneurysms of the posterior cerebral artery: do they present specific characteristics? Acta Neurochir (Wien). 1996;138:840-52.

9. Andreou A, I. Ioannidis I, Mitsos A. Endovascular treatment of peripheral intracranial aneurysms. AJNR Am J Neuroradiol. 2007;28(2):355-61.
10. Hess A, Klein I, Iung B, Lavallée P, Ilic-Habensus E, Dornic $\mathrm{Q}_{2}$ et al. Brain MRI findings in neurologically asymptomatic patients with infective endocarditis. AJNR Am J Neuroradiol. 2013;34(8):1579-84. doi: 10.3174/ajnr.A3582.

11. Cognard C, Weill A, Tovi M, Castaings L, Rey A, Moret J. Treatment of distal aneurysms of the cerebellar arteries by intraaneurysmal injection of glue. Am J Neuroradiol. 1999; 20:780-4.

12. Steinberg GK, Guppy KH, Adler JR, Silverberg GD. Stereotactic, angiography-guided clipping of a distal, mycotic intracranial aneurysm using the Cosman-Roberts-Wells system: technical note. Neurosurgery. 1992;30:408-11. doi: 10.1227/ 00006123-199203000-00016.

13. Petr O, Brinjikji W, Burrows AM, Cloft H, Kallmes DF, Lanzino G. Safety and efficacy of endovascular treatment for intracranial infectious aneurysms: a systematic review and metaanalysis. J Neuroradiol. 2016;43(5):309-16. doi: 10.1016/j. neurad.2016.03.008.

14. Chapot R, Houdart E, Saint-Maurice JP, Aymard A, Mounayer C, Lot G, et al. Endovascular treatment of cerebral mycotic aneurysms. Radiology. 2002;222(2):389-96. doi: 10.1148/ radiol.2222010432.

15. Chun JY, Smith W, Van Halbach V, Higashida RT, Wilson CB, Lawton MT. Current multimodality management of infectious intracranial aneurysms. Neurosurgery. 2001;48 (6):1203-14. doi: 10.1097/00006123-200106000-00001.

16. Khayata MH, Aymard A, Casasco A, Herbreteau D, Woimant F, Merland JJ. Selective endovascular techniques in the treatment of cerebral mycotic aneurysms. J Neurosurg. 1993;78:6615. doi: 10.3171/jns.1.

17. Chen Z, Yang Y, Miao H, Chen J, Luo C, Feng H, et al. Endovascular treatment of ruptured peripheral intracranial aneurysms. Neurosciences (Riyadh). 2012;17:133-8.

18. Piepgras DG, McGrail KM, Tazelaar HD. Intracranial dissection of the distal middle cerebral artery as an uncommon cause of distal cerebral artery aneurysm. Case report. J Neurosurg. 1994;80:909-13. doi: 10.3171/jns.1994.80.5.0909.

19. Taqi MA, Lazzaro MA, Pandya DJ, Badruddin A, Zaidat OO. Dissecting aneurysms of posterior cerebral artery: clinical presentation, angiographic findings, treatment, and outcome. Front Neurol. 2011:2:38.

20. Matsubara N, Miyachi S, Izumi T, Yamanouchi T, Asai T, Ota $\mathrm{K}$, et al. Results and current trends of multimodality treatment for infectious intracranial aneurysms. Neurol Med Chir (Tokyo). 2015;55(2):155-62. doi: 10.2176/nmc.oa.2014-0197.

21. Andoh T, Itoh T, Yoshimura S, Shirakami S, Nakashima T, Nishimura $Y$, et al. Peripheral aneurysms of the posterior inferior cerebellar artery: analysis of 15 cases. No Shinkei Geka. 1992;20:683-90.

22. Spallone A, De Santis S, Giuffre R. Peripheral aneurysms of the anterior inferior cerebellar artery: case report and review of literature. Br J Neurosurg. 1995;9:537-41.

23. Gross BA, Puri AS. Endovascular treatment of infectious intracranial aneurysms. Neurosurg Rev. 2013;36(1):11-9. doi: 10.1007/s10143-012-0414-1. 
24. Cagnazzo F, Perrini P, Dargazanli C, Lefevre PH, Gascou G, Morganti R, et al. Treatment of unruptured distal anterior circulation aneurysms with flow-diverter stents: a meta-analysis. AJNR Am J Neuroradiol. 2019;40(4)687-93. doi: 10.3174/ajnr. A6002.

25. Ravindran K, Enriquez-Marulanda A, Kan PTM, Renieri L, Limbucci N, Mangiafico S, et al. Use of flow diversion for the treatment of distal circulation aneurysms: a multicohort study. World Neurosurg. 2018;118:e825-e833. doi: 10.1016/j.wneu. 2018.07.062.

26. Chalouhi N, Tjoumakaris S, Gonzalez LF, Hasan D, Alkhalili $\mathrm{K}$, Dumont AS, et al. Endovascular treatment of distal intracranial aneurysms with Onyx 18/34. Clin Neurol Neurosurg. 2013;115(12):2528-32. doi: 10.1016/j.clineuro.2013.10.018.

27. Lv N, Zhou Y, Yang P, Li Q, Zhao R, Fang Y, et al. Endovascular treatment of distal middle cerebral artery aneurysms: report of eight cases and literature review. Interv Neuroradiol. 2016;22(1):12-7. doi: 10.1177/1591019915617317.

28. Anil G, Sein L, Nga V, Teo K, Chou N, Yeo TT. Dissecting distal cerebellar artery aneurysms: options beyond a parent vessel sacrifice. Neurosurg Rev. 2020;43(2):771-80. doi: 10.1007/ s10143-019-01119-y.

29. Sakata S, Fujii K, Matsushima T, Fujiwara S, Fukui M, Matsubara T. Aneurysm of the posterior cerebral artery: report of eleven cases - surgical approaches and procedures. Neurosurgery. 1993;32:163-8.

30. Xu J, Xu L, Wu Z, Chen X, Yu J, Zhang J. Fetal-type posterior cerebral artery: the pitfall of parent artery occlusion for ruptured P2 segment and distal aneurysms. J Neurosurg. 2015; 123(4):906-14. doi: 10.3171/2014.9.JNS1442.

31. Sturiale CL, Waure CD, Pepa GMD, Calabrò GE, Albanese A, D'Argento F, et al. Endovascular treatment of the posterior cerebral artery aneurysms: single-center experience and a systematic review. World Neurosurg. 2016;91:154-62. doi: 10.1016/j.wneu.2016.03.083.

32. Schievink WI, Wijdicks EF, Piepgras DG, Chu-Pin Chu, O'Fallon M, Whisnant JP. The poor prognosis of ruptured intracranial aneurysms of the posterior circulation. J Neurosurg. 1995;82:791-5. doi: 10.3171/jns.1995.82.5.0791.

33. Suzuki O, Miyachi S, Negoro M, Okamoto T, Sahara Y, Hattori $\mathrm{K}$, et al. Treatment strategy for aneurysms of the posterior cerebral artery. Interv Neuroradiol. 2003;9(Suppl 1):83-8. doi: 10.1177/15910199030090S110.
34. Kashiwazaki D, Ushikoshi S, Asano T, Osanai T, Kuroda S, Houkin K. Endovascular treatment for aneurysms of the posterior cerebral artery: 12 years' experience with 21 cases. Acta Neurochir (Wien). 2011;153:2151-8.

35. van Rooij WJ, Sluzewski M, Beute GN. Endovascular treatment of posterior cerebral artery aneurysms. AJNR Am J Neuroradiol. 2006;27:300-5.

36. Yamahata $H$, Tokimura $H$, Hirabaru M, Hirano $H$, Arita $H$. Aneurysm on the cortical branch (P4 segment) of the posterior cerebral artery. Neurol Med Chir (Tokyo). 2010;50:1084-7.

37. Ciceri E, Klucznik R, Grossman R, Rose JE, Mawad ME. Aneurysms of the posterior cerebral artery: classification and endovascular treatment. AJNR Am J Neuroradiol. 2001;22: 227-34.

38. Hallacq P, Piotin M, Moret J. Endovascular occlusion of the posterior cerebral artery for the treatment of $\mathrm{P} 2$ segment aneurysms: retrospective review of 10-year series. AJNR Am J Neuroradiol. 2002;23:1128-36.

39. Liu L, He H, Jiang C, Lv X, Li Y. Deliberate parent artery occlusion for non-saccular posterior cerebral artery aneurysms. Interv Neuroradiol. 2011;17:159-68.

40. Kim JH, Chang CH, Jung YJ. A pseudoaneurysm associated with a ruptured cerebral aneurysm: hypothesis on the formation of the PA and feasibility of endovascular treatment. J Cerebrovasc Endovasc Neurosurg. 2018;20(1):24-7. doi: 10.7461/jcen.2018.20.1.24.

41. Zheng Y, Lu Z, Shen J, Xu F. Intracranial pseudoaneurysms: evaluation and management. Front Neurol. 2020;11:582. doi: 10.3389/fneur.2020.00582.

42. Lampert TE, Halbach VV, Higashida RT, Dowd CF, Urwin RW, Balousek PA, et al. Endovascular treatment of pseudoaneurysms with electrolytically detachable coils. AJNR Am J Neuroradiol. 1998;19:907-11.

43. Nomura M, Mori K, Tamase A, Kamide T, Seki S, Iida Y, et al. Pseudoaneurysm formation due to rupture of intracranial aneurysms: case series and literature review. Neuroradiol J. 2017;30(2):129-37. doi: 10.1177/1971400916684667.

44. Gitto L, Richardson TE, Serinelli S. Diana F, Peschillo S, Domenicucci M. Massive intracranial bleeding due to the rupture of a rare spontaneous pseudoaneurysm of the middle cerebral artery in a pediatric patient: case report with clinical, radiological, and pathologic findings. Forensic Sci Med Pathol. 2019;15:474-80. doi: 10.1007/s12024-019-00122-5. 


\title{
Sažetak \\ ENDOVASKULARNO LIJEČENJE INTRAKRANIJSKIH ANEURIZMI DISTALNIH ARTERIJSKIH OGRANAKA: ILUSTRATIVNI PRIKAZ SLUČAJEVA I UVID U DOSADAŠNJU LITERATURU
}

\author{
K. Rotim, B. Splavski, V. Kalousek, M. Jurilj i T. Sajko
}

Intrakranijske se aneurizme distalnih arterijskih ogranaka javljaju sporadično i rijetko. One predstavljaju 2\%-7\% aneurizmi srednje moždane arterije i 0,7\%-2,3\% aneurizmi stražnje moždane arterije, gdje uglavnom nastaju na odsječku P2 i distalno od njega. Ovakve aneurizme najčešće ostaju asimptomatske i samim time neprepoznate prije nego rupturiraju, što čini njihovo dijagnosticiranje i liječenje iznimno zahtjevnim. Endovaskularno liječenje koje se sastoji od uporabe različitih neurointervencijskih tehnika postaje najučinkovitiji suvremeni rutinski pristup u opskrbi aneurizmi distalnih arterijskih cerebralnih ogranaka. U našem institucijskom prikazu slučajeva endovaskularno selektivno postavljanje zavojnica i/ili okluzija matične krvne žile rezultirali su uspješnim i potpunim isključenjem aneurizme iz moždane cirkulacije, što je osiguralo dobar oporavak bolesnika. U radu predstavljamo ilustrativni prikaz slučajeva bolesnika s intrakranijskim aneurizmama distalnih arterijskih ogranaka, raspravljajući o mogućim uzrocima njihovog nastanka i oblicima endovaskularnog liječenja. Također donosimo uvid u dosadašnju literaturu povezanu s ovom rijetkom bolesti. Zaključujemo kako bi aneurizme distalnih moždanih arterijskih ogranaka trebalo opskrbiti rano i agresivno zbog njihove sklonosti rupturi. Uvjereni smo kako je endovaskularno selektivno postavljanje zavojnica metoda izbora u liječenju, dok je okluzija matične krvne žile (pomoću tekućeg embolizacijskog sredstva) optimalna u slučaju kada nije moguće postaviti zavojnice u aneurizmatsku tvorbu, odnosno kada je distalno kortikalno područje dobro prokrvljeno snažnom kolateralnom moždanom cirkulacijom.

Ključne riječi: Cerebralni arterijski ogranci, distalni; Aneurizma, intrakranijska; Endovaskularno liječenje 